the University of Melbourne. He shared the David Syme Research Prize of the University of Melbourne in 1954, was elected a Fellow of the Royal Australian Chemical Institute in 1952 and a Fellow of the Australian Academy of Science in 1964. He was appointed an Officer of the Order of the British Empire in 1965 and in the same year he was awarded a senior foreign scientist fellowship by the National Science Foundation to work at the University of Missouri which he will take up in 1966. He has held various offices with the Royal Australian Chemical Institute, the Institute of Medical Laboratory Technology and the Victorian Society of Pathology and Experimental Medicine.

\section{Statistics in the University of Edinburgh:}

Prof. D. J. Finney, F.R.S.

Prof. D. J. Finney has been appointed to the newly instituted chair of statistics in the University of Edinburgh as from September 1966. Prof. Finney, who is well known for his work in statistics, is at present professor of statistics in the University of Aberdeen. He was born in Lancashire and educated at Lymm and Manchester Grammar Schools before obtaining an Open Scholarship at Clare College, Cambridge, where he graduated in mathematics in 1937. He took his M.A. in 1941, and a D.Sc. at Cambridge in 1947. After two years' research at Cambridge and London, he was from 1939 until 1945 assistant statistician at Rothamsted Experimental Station and, from 1945 until 1954, lecturer in the design and analysis of scientific equipment at the University of Oxford. In 1954 he moved to Aberdeen as reader in statistics, and director of the Agricultural Research Council Unit of Statistics. He was appointed to the chair of statistics in Aberdeen in 1963. In addition he has acted as consultant statistician to numerous institutions; he was visiting professor at the University of North Carolina in 1949, and at Harvard in 1962-63. Since 1961 he has been honorary director of the Research Group in Biometric Medicine of the Scottish Hospitals Endowments Research Trust, and since 1963 a member of the Adverse Reactions Sub-Committee of the Committee on the Safety of Drugs. $\mathrm{He}$ is a vice-president and past-president of the Biometric Society, a former vice-president of the Royal Statistical Society, and a member of numerous other societies in the fields of statistics and genetics. Although originally a mathematician, Prof. Finney is primarily interested in the application of statistical methods to biology, including agriculture and medicine. His research has been particularly concerned with statistical estimation, biological assay, experimental design, human genetics, screening and selection, and forest sampling.

\section{Bland-Sutton Institute of Pathology:}

Prof. R. W. Scarff

Prof. R. W. SCarfF, who retires this month, has for the past seventeen years been director of the BlandSutton Institute of Pathology at the Middlesex Hospital Medical School and responsible for all the teaching, research and routine hospital pathological investigations carried out there. Himself a student of the Middlesex, he joined the staff of the Bland-Sutton Institute in 1924 shortly after qualifying. The title of professor of morbid anatomy and histology was conferred on him in 1946, and two years later he succeeded Prof. J. McIntosh as director and professor of pathology. The Bland-Sutton has always had a reputation for cancer research, and Prof. Scarff has done much to enhance this. He has for long been closely connected with the British Empire Cancer Campaign for Research, having been appointed secretary of its Scientific Advisory Committee in 1935, a post he held until 1954 when he became honorary secretary. Nearly twenty years ago, sensing the need for a new publication to deal with the rapidly increasing number of papers on cancer research, he started, and became editor of, the British Journal of Cancer, under the auspices of the British Empire Cancer Campaign for Research. This new Journal he developed along the same lines as the British Journal of Experimental Pathology, which he was already editing at that time. A highlight in his career was the 1958 International Cancer Congress held in London, for the great success of which he was, as secretary-general, largely responsible. Prof. Scarff's personal research work has covered a variety of subjects through the years, but has mainly been connected with malignant disease, and in 1958 he was appointed head of a World Health Organization International Reference Centre for the study of mammary tumours. Since 1960 he has been consultant adviser in pathology to the Ministry of Health, while among his increasing international activities has been his appointment as secretary and treasurer of the International Council of Societies of Pathology, in the formation of which body he played a leading part.

Prof. G. Dick

Prof. G. Dick has been appointed to succeed Prof. R. W. Scarff as from April 1, 1966. Prof. Dick will direct the Bland-Sutton Institute and head the Department of Medical Microbiology. After graduating M.B., Ch.B. at the University of Edinburgh in 1938 and B.Sc. with first-class honours in pathology in 1939 , he served as pathologist in the Royal Army Medical Corps in Africa during the Second World War. In 1946 he joined the Colonial Medical Research Service and worked in Uganda on the natural history of yellow fever and other arboviruses. He was awarded a Rockefeller Foundation fellowship in 1948 and worked in New York and Baltimore on the relationship of Mengo virus to encephalomyocarditis virus and on methods of preparing inactivated poliovirus vaccines. In 1949 he graduated M.P.H. at Johns Hopkins University. In 1951 he became a member of the scientific staff of the Medical Research Council and worked at Mill Hill on the aetiology of mouse hepatitis. Since 1955 he has held the chair of microbiology at the Queen's University, Belfast. During this period he has worked on the development and evaluation of poliovirus vaccines. He has served on several Medical Research Council and Ministry of Health committees concerned with problems of immunization against virus diseases. Prof. Dick graduated M.D. in 1949 and D.Sc. in 1958. $\mathrm{He}$ was awarded the Singapore Gold Medal on both occasions. $\mathrm{He}$ was admitted M.R.C.P.(Edin.) in 1953 and elected Fellow in 1955, and was admitted M.R.C.P.(Lond.) in 1960 and F.C.Path. in 1964.

\section{Zoology and Comparative Physiology in the University of Birmingham : Prof. L. H. Finlayson}

DR. L. H. Finlayson, senior lecturer in the Department of Zoology and Comparative Physiology in the University of Birmingham, has been appointed to the second chair in the Department of Zoology and Comparative Physiology in that University. Dr. Finlayson was educated at Kilmarnock Academy and the University of Glasgow, where he obtained a first-class honours degree in zoology in 1945. Having served for a year in the Pest Infestation Laboratory at Slough, he was appointed to the staff of the Department of Zoology at Birmingham, where hebecame senior lecturer in 1960. In 1952-53 he held a Rockefeller Foundation fellowship at Harvard, and in 1964-65 he was temporarily seconded to the Medical School of the University College of Southern Rhodesia and Nyasaland to fill the place of reader in biological sciences. Dr. Finlayson has worked in various fields of experimental entomology and is internationally known for his work on the fate of certain insect muscles during metamorphosis 